\title{
Relating large-scale climate variability to local species abundance: ENSO forcing and shrimp in Breton Sound, Louisiana, USA
}

\author{
Bryan P. Piazza ${ }^{1,4, *}$, Megan K. La Peyre ${ }^{2}$, Barry D. Keim ${ }^{3}$ \\ ${ }^{1}$ School of Renewable Natural Resources, Louisiana State University Agricultural Center, Baton Rouge, Louisiana 70803, USA \\ ${ }^{2}$ USGS Louisiana Fish and Wildlife Cooperative Research Unit, School of Renewable Natural Resources, \\ Louisiana State University Agricultural Center, Baton Rouge, Louisiana 70803, USA \\ ${ }^{3}$ Louisiana Office of State Climatology, Department of Geography and Anthropology, Louisiana State University, Baton Rouge, \\ Louisiana 70803, USA \\ ${ }^{4}$ Present address: The Nature Conservancy, PO Box 4125, Baton Rouge, Louisiana 70821, USA
}

\begin{abstract}
Climate creates environmental constraints (filters) that affect the abundance and distribution of species. In estuaries, these constraints often result from variability in water flow properties and environmental conditions (i.e. water flow, salinity, water temperature) and can have significant effects on the abundance and distribution of commercially important nekton species. We investigated links between large-scale climate variability and juvenile brown shrimp Farfantepenaeus aztecus abundance in Breton Sound estuary, Louisiana (USA). Our goals were to (1) determine if a teleconnection exists between local juvenile brown shrimp abundance and the El Niño Southern Oscillation (ENSO) and (2) relate that linkage to environmental constraints that may affect juvenile brown shrimp recruitment to, and survival in, the estuary. Our results identified a teleconnection between winter ENSO conditions and juvenile brown shrimp abundance in Breton Sound estuary the following spring. The physical connection results from the impact of ENSO on winter weather conditions in Breton Sound (air pressure, temperature, and precipitation). Juvenile brown shrimp abundance effects lagged ENSO by 3 mo: lower than average abundances of juvenile brown shrimp were caught in springs following winter El Niño events, and higher than average abundances of brown shrimp were caught in springs following La Niña winters. Salinity was the dominant ENSO-forced environmental filter for juvenile brown shrimp. Spring salinity was cumulatively forced by winter river discharge, winter wind forcing, and spring precipitation. Thus, predicting brown shrimp abundance requires incorporating climate variability into models.
\end{abstract}

KEY WORDS: Climate variability $\cdot$ ENSO $\cdot$ El Niño $\cdot$ La Niña $\cdot$ Farfantepenaeus aztecus $\cdot$ Shrimp Estuary $\cdot$ Louisiana

Resale or republication not permitted without written consent of the publisher

\section{INTRODUCTION}

Climate influences local community structure by creating environmental constraints (filters) that affect the abundance and distribution of species (Tonn 1990, Weiher \& Keddy 1999). These constraints can be direct or indirect and result from environmental forcing, species interactions, or both (Stenseth et al. 2002). Many studies have linked large-scale climate with effects on plants and animals in terrestrial and aquatic ecosystems largely through the influence of local meteorological parameters and associated environmental conditions (Blenckner \& Hillebrand 2002, Stenseth et al. 2002).

Commercial fish stocks are also susceptible to largescale climate forcing through variability in environmental filters (i.e. water flow, salinity, water temperature) that affect their abundance and distribution 
(Zimmerman et al. 2000, Garcia et al. 2004, Meynecke et al. 2006). Northern Gulf of Mexico (GOM) estuaries support $66 \%$ of the US harvest of penaeid shrimps (Farfantepenaeus aztecus, F. duorarum, Litopenaeus setiferus) and $25 \%$ of the US harvest of blue crabs Callinectes sapidus (Zimmerman et al. 2000). While many studies in the region have linked these species to environmental forcing conditions (salinity, water temperature, water level; Zimmerman et al. 2000, Haas et al. 2001, 2004, Roth et al. 2008), few have linked that environmental forcing to large-scale climate processes (but see Childers et al. 1990, Kim \& Powell 1998, Soniat et al. 2005, 2009). Given the importance of the GOM to US fisheries and the projected climatic effects on estuarine conditions (e.g. sea level, river discharge), the ability to predict effects of large-scale climate forcing on commercial fish stocks will be critical for future fisheries management (Zimmerman et al. 2000, Christensen et al. 2007, Palmer et al. 2008). The objective of this study was to investigate the links between largescale climate variability and juvenile brown shrimp F. aztecus abundance in Breton Sound estuary, Louisiana. Specifically, the goals were to (1) determine whether a teleconnection exists between local juvenile brown shrimp abundance and the El Niño Southern Oscillation (ENSO) and (2) relate that linkage to environmental filters that may affect juvenile brown shrimp recruitment to and survival in the estuary.

ENSO is one of the most prominent sources of largescale climate variability worldwide (Glantz 1996, Trenberth \& Caron 2000) and refers to the interannual climate signal resulting from atmospheric response to sea surface temperature (SST) fluctuations in the equatorial Pacific Ocean (Trenberth 1997, Trenberth \& Caron 2000). During El Niño (the warm phase of ENSO), SST increases in central and eastern portions of the equatorial Pacific. El Niño events are characterized by an atmospheric pressure pattern that decreases from west to east, a corresponding weakening of the easterly trade winds, and increased atmospheric heating in the central and eastern Pacific Ocean. La Niña (the cool phase of ENSO) is characterized by an SST decrease in the equatorial Pacific, causing opposite temperature and pressure conditions from El Niño. ENSO events occur with a periodicity of ca. 3 to 5 yr (Graham \& White 1988). As a consequence of the variability in atmospheric conditions, ENSO events influence local and regional weather patterns across the globe largely through their effect on the jet stream, cyclogenesis, and the steering of tropical cyclones, and these effects often differ regionally (Ropelewski \& Halpert 1987, Noel \& Changnon 1998, Trenberth \& Caron 2000).

ENSO events have been related to variability in environmental forcing conditions that affect commercially important marine and estuarine species world- wide (Stenseth et al. 2002). The resulting environmental filters have been shown to affect populations of the commercially important bivalve Donax dentifer in Malága Bay, Colombia (Riascos 2006), Peruvian anchovy off the eastern coast of South America (Stenseth et al. 2002), bigeye tuna Thunnus obesus in the Indian Ocean (Ménard et al. 2007), skipjack tuna Katsuwonus pelamis in the western Pacific Ocean (Lehodey et al. 1997), salmon (Salmonidae) in the North Pacific basin (Mantua et al. 1997), penaeid prawns (Penaeidae) and mullet (Mugil spp.) in Australian estuaries (Meynecke et al. 2006), pink shrimp in Brazilian lagoons (Möller et al. 2009), and Eastern oysters Crassostrea virginica in northern GOM estuaries (Kim \& Powell 1998, Soniat et al. 2005, 2009).

ENSO conditions have been related to variability in weather conditions in the southeastern United States (Schmidt et al. 2001, McCabe \& Muller 2002). ENSOrelated weather effects in this region occur primarily in winter and result from variability in the frequency and intensity of 2 synoptic weather types - frontal overrunning and Gulf Return (McCabe \& Muller 2002). El Niño winters are marked by an increase in the frequency and intensity of frontal overrunning conditions, causing cloudiness, cool temperatures, and northerly (offshore) winds. La Niña winters are marked by an increase in the frequency and intensity of the Gulf Return weather type, causing warm, dry conditions, dominated by south and southeasterly (onshore) winds. These differences in regional climate conditions have been related to variability in local sea level (Kennedy et al. 2007), river discharge (Schmidt et al. 2001), water quality (Lipp et al. 2001), and salinity patterns (Schmidt \& Luther 2002, Tolan 2007) in northern GOM estuaries.

The brown shrimp Farfantepenaeus aztecus is 1 of 2 commercially important penaeid shrimp species harvested in Louisiana. Like other estuarine-dependent species, brown shrimp are dependent on estuarine nursery areas during the juvenile life stage (Larson et al. 1989, Haas et al. 2004). Adult brown shrimp spawn offshore, and larvae are advected to the estuary by near-shore currents. Post-larvae settle in the estuary, and juveniles grow rapidly before migrating back offshore to spawn. Brown shrimp have an annual life cycle, making larval recruitment to the estuary, as well as juvenile growth and survival while in the estuary, very important to the year class strength of this important fishery resource (Haas et al. 2001). Therefore, climate-related effects on recruitment, growth, and survival may be important regulators of the fishery. While this recruitment-growth-migration cycle for brown shrimp happens throughout the year, the largest pulse of post-larval brown shrimp settles in Louisiana estuaries during late winter and early spring. It is then, when the effects of potential ENSO- 
related environmental filters (e.g. river discharge, wind forcing, salinity, water temperature) may affect their abundance and ultimately, their recruitment into the fishery (Haas et al. 2004). As such, this paper addresses the association between juvenile brown shrimp abundance and ENSO and its environmental impacts in Breton Sound, Louisiana.

\section{MATERIALS AND METHODS}

\subsection{Study area}

We studied the effect of ENSO on brown shrimp abundance from 19882007 in Breton Sound estuary, Louisiana (Fig. 1). Breton Sound is a 271000 ha estuary in the Mississippi River deltaic plain in southeast Louisiana. It is microtidal and consists of bays, lakes, bayous, canals, and fresh, intermediate, brackish, and saline marsh types. The upper estuary is separated into east and west com-

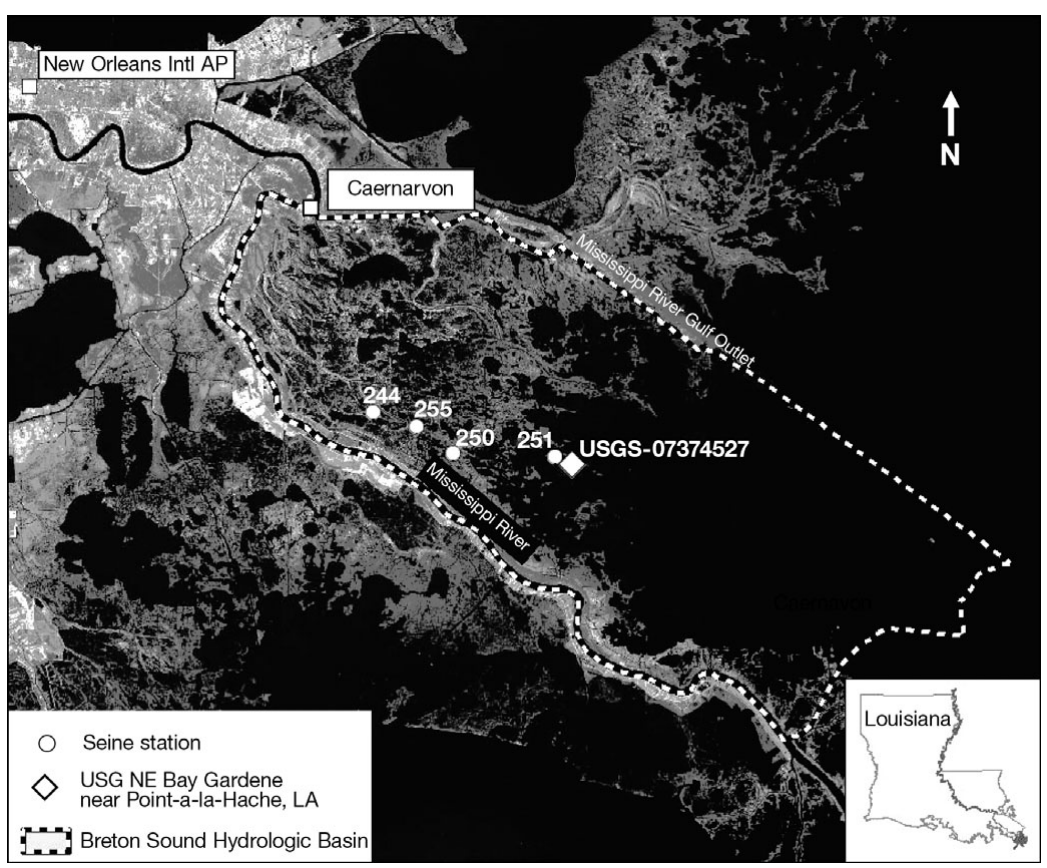

Fig. 1. Breton Sound estuary, Louisiana, USA. Dots: 4 fisheries independent seine net collection stations used in this study. Diamond: USGS 07374527 Northeast Bay Gardene near Point-a-la-Hache. Squares: New Orleans International Airport (Stn ID 166295) and Caernarvon

\subsection{Data sources}

\subsubsection{Brown shrimp abundance data} estuary consists of saltmeadow cordgrass Spartina patens and chairmaker's bulrush Schoenoplectus americanus in upper basin marshes, eventually yielding to smooth cordgrass Spartina alterniflora and black needlerush Juncus roemerianus in lower basin marshes. The Caernarvon Freshwater Diversion structure (Caernarvon), located at the head of Breton Sound, became operational in 1991 and is capable of delivering substantial amounts of fresh water $\left(227 \mathrm{~m}^{3} \mathrm{~s}^{-1}\right)$ and allochthonous sediments $\left(4.5 \times 10^{8} \mathrm{~kg} \mathrm{yr}^{-1}\right)$ to the basin (Snedden et al. 2007a). Winter/spring high-flow freshwater pulsing of the diversion structure began in spring 2001 to simulate seasonal flood-pulse events. Pulses release periodic large fluxes of river water into the basin and are capable of inundating upper basin marshes ( 5700 ha) for several days (Snedden et al. 2007a,b, Piazza \& La Peyre 2007). Prior to construction of the Caernarvon diversion, natural distributaries in the upper basin were severed from the estuary by flood control levees along the Mississippi River, and without the riverine pulse, inundation of upper basin marshes is dominated by meteorological forcing. Water levels in midand lower-basin marshes, as well as in marshes east of Bayou Terre Aux Boeufs, are dominated by meteorological forcing conditions year-round, as is typical in northern GOM estuaries (Rozas 1995, Rozas et al. 2005).
Juvenile brown shrimp abundance was compiled from 4 fishery independent seine $(15 \mathrm{~m}$ nylon bag seine; $6 \mathrm{~mm}$ mesh) stations in Breton Sound (station IDs: 244, 255, 250, 251; Fig. 1). These stations roughly form a west-northwest to east-southeast transect, whereby Stn 244 is the northwesternmost station and is located closest to Caernarvon, and Stn 251 is the station farthest to the east-southeast, and is situated nearest the GOM. Stations were sampled approximately every 2 weeks from 1988-2007 by the Louisiana Department of Wildlife and Fisheries (LDWF). Bag seine stations are used to monitor juvenile finfish, shellfish, and other marine organisms (LDWF 2002), and long-term seine data are a useful index of relative abundance and seasonal/long-term trends. Seine samples were collected over soft bottom areas by attaching $30 \mathrm{~m}$ lengths of $1.3 \mathrm{~cm}$ nylon rope to each of two $2 \mathrm{~m}$ seine pole bridles anchored to the shoreline. After fully extending the line, the seine was fed out parallel to the shoreline. The seine was then hauled in by the 2 tow lines, and the contents were removed from the bag. Seine samples collected over hard bottom areas were performed by stretching the net and pulling parallel to the shoreline for a distance of approximately $25 \mathrm{~m}$. The 
outside end was brought toward the shoreline, the net was drawn ashore, and the contents removed (LDWF 2002).

Empirical orthogonal function (EOF) analysis was performed on monthly mean brown shrimp abundance (from each station) as an exploratory tool to examine the spatiotemporal variability in the variable (Emery \& Thompson 1998). The analysis showed that abundance and variability in shrimp catch was strongly dominated by Stn 250 . Likewise, because of the migratory nature of brown shrimp, populations are generally much higher during the spring months. As a result, brown shrimp abundance data were normalized by the mean and SD (Burd \& Jackson 2002) to create a standard score that takes into account this spatial and temporal variation, such that the standardized value is negative when the raw score is below the mean and positive when above. An EOF analysis was then performed on the normalized brown shrimp abundance, and the analysis revealed that the first mode accounted for almost half $(46 \%)$ of the variability in the data and showed the basin (all stations) fluctuating in unison. Therefore, brown shrimp abundance values for each station were pooled into a combined brown shrimp variable $\left(X_{\text {com }}\right)$ that was computed as follows:

$$
X_{\text {com }}=\frac{1}{4} \sum X_{\text {sta }}
$$

where $X_{\mathrm{stn}}$ is the mean monthly value for each station $(244,255,250,251)$. Monthly mean values were then calculated for the new (combined and normalized) brown shrimp abundance variables.

\subsubsection{Environmental data}

Discrete water temperature $\left({ }^{\circ} \mathrm{C}\right)$ and salinity (PSU) measurements were collected at each seine station in Breton Sound in conjunction with biological sampling throughout the entire period of record (1988-2007). These discrete measurements were checked against hourly continuous measurements collected at several stations in the basin to ensure that they were accurate indicators of environmental conditions in the basin. The results indicated that the discrete measurements correlated with measurements from all continuous stations. Therefore, the discrete salinity and water temperature measurements were used in the analyses. As with the brown shrimp data, EOF analysis showed a highly significant first mode that dominated the variability for both water temperature (93\%) and salinity $(82 \%)$. This mode for both variables showed the basin fluctuating in unison. Therefore, water temperature and salinity values for each station were pooled into combined water temperature and salinity variables, similar to the brown shrimp abundance data, and monthly means were calculated for the entire time series.

Hourly real-time water level data were gathered from USGS 07374527 Northeast Bay Gardene near Point-a-la-Hache, Louisiana (1992-2007; Fig. 1), and monthly mean water level values were calculated for the entire time series.

\subsubsection{Climate and meteorological data}

The state of ENSO was measured by using the monthly Niño 3.4 SST anomaly index for the tropical Pacific rectangle $\left(5^{\circ} \mathrm{N}-5^{\circ} \mathrm{S}, 120-170^{\circ} \mathrm{W}\right.$; Trenberth 1997), taken from the National Weather Service, Climate Prediction Center (www.cpc.ncep.noaa.gov/data/ indices/). The Niño 3.4 index describes SST anomalies relative to a base period climatology and serves as a proxy for the overall ENSO condition (Stenseth et al. 2002). Months were defined as belonging to El Niño, La Niña, or neutral conditions, based on a 5 mo running mean of the Niño 3.4 SST anomaly index (hereafter SSTA). El Niño months exceeded $+0.4^{\circ} \mathrm{C}$ above the mean. La Niña months exceeded $-0.4^{\circ} \mathrm{C}$ below the mean, and neutral months fell between $\pm 0.4^{\circ} \mathrm{C}$ of the mean. Monthly ENSO designations were compared against the literature (Trenberth 1997, Lipp et al. 2001, Twine et al. 2005), and there was agreement in the monthly classification.

Hourly real-time measurements of meteorological variables were collected for 1988-2007 from New Orleans Louis Armstrong International Airport (ID 166295), located approximately $55 \mathrm{~km}$ to the northwest of the study area. Variables included atmospheric pressure $(\mathrm{mb})$, precipitation $(\mathrm{cm})$, air temperature $\left({ }^{\circ} \mathrm{C}\right)$, wind speed $\left(\mathrm{m} \mathrm{s}^{-1}\right)$, and wind direction $\left(^{\circ}\right)$. As with the environmental data, these data were checked against shorter time series from continuous recorder stations located in and near Breton Sound, and, like the environmental data, the measurements from New Orleans airport correlated with measurements from all stations. Therefore, the measurements from the airport were used in the analyses. Monthly mean values were calculated for each meteorological variable. To calculate mean monthly values for wind speed and direction, hourly wind vectors were first rotated to represent a wind blowing toward the direction of the vector $\left({ }^{\circ} \mathrm{T}\right)$, and unit vector averages were calculated on the rotated vectors.

\subsubsection{Remote wind forcing}

Previous researchers have shown that during spring, sea level in Breton Sound is forced by a combination of river discharge (upper estuary) and remote alongshore 
wind forcing (entire estuary; Snedden et al. 2007b). Remote alongshore wind forcing acts to facilitate estuary-shelf water exchange through Ekman pumping. In Breton Sound, wind stress and coastal sea level are most coherent along the $110^{\circ}-290^{\circ}$ component (Snedden et al. 2007b). Consequently, northwest winds (blowing southeastward $110^{\circ} \mathrm{T}$ ) produce the greatest decrease in estuarine water levels, and southeast winds (blowing northwestward $290^{\circ} \mathrm{T}$ ) produce the greatest increases in estuarine water levels. Because brown shrimp recruitment is dependent on onshore flow, this information was used to create a wind forcing index that served as a proxy for brown shrimp 'stocking' currents. To do this, hourly wind vectors were rotated along the $110^{\circ}-290^{\circ}$ component and multiplied by the Cartesian coordinates (uu, vv) of the vector to produce a scalar wind speed $\left(\mathrm{m}^{3} \mathrm{~s}^{-1}\right)$ along the $110^{\circ}-290^{\circ}$ component. Positive values indicate a southeast 'stocking' wind (blowing northwestward $\left.290^{\circ} \mathrm{T}\right)$.

\subsubsection{Mississippi River discharge}

Daily Mississippi River discharge (Q) data were collected for 1988-2007 from the station at Tarbert Landing, Mississippi (Gage ID USACE 01100), and monthly mean values were calculated for the entire time series. This station was chosen because it is upstream from the Louisiana coastal zone. Therefore, it represents river discharge independent of the effects of local precipitation, runoff, and the effects of flood control projects and freshwater diversions in Louisiana, upstream from Breton Sound.

\subsection{Yearly anomaly calculations}

To examine the hypothesis that winter ENSO conditions affect spring abundance of juvenile brown shrimp, we created a winter-spring seasonal subset. For convenience and ease in interpretation, months were further classified into seasons based on the following definitions: winter (January-March) and spring (April-June). Yearly anomalies were then calculated for winter and spring seasons (Kimmel et al. 2006). Yearly winter anomalies were calculated for SSTA, meteorological variables (air pressure, air temperature, precipitation, wind forcing), and environmental variables (salinity, water temperature, water level, Q). Yearly spring anomalies were also calculated for the meteorological variables, environmental variables, and juvenile brown shrimp abundance. To calculate the winter anomalies, mean monthly values $\left(Y_{\mathrm{m}}\right)$ were used to calculate a winter seasonal average $\left(Y_{\text {win }}\right)$ :

$$
Y_{\text {win }}=\frac{1}{3} \sum_{i=\mathrm{Jan}}^{\text {March }} Y_{\mathrm{m}}
$$

where $Y$ is the variable of interest (SSTA, air pressure, air temperature, precipitation, wind forcing, salinity, water temperature, water level, or Q). Next, we calculated

$$
Y_{\mathrm{LTM}}=\frac{1}{n} \sum Y_{\mathrm{win}}
$$

where $Y_{\text {LTM }}$ is the long-term arithmetic mean, and $n$ is the number of years (20) in the period 1988-2007. The winter anomaly $\left(A_{\mathrm{Y}}\right)$ was then calculated for each year by using the formula:

$$
A_{\mathrm{Y}}=Y_{\text {win }}-Y_{\mathrm{LTM}}
$$

where $Y_{\text {win }}$ is the winter seasonal average. This process was repeated with the mean monthly spring values (April to June) to calculate a spring average anomaly $\left(A_{\mathrm{Z}}\right)$.

\subsection{Statistical analyses}

The first step to determine if a teleconnection exists between ENSO and local juvenile brown shrimp abundance was to establish whether ENSO affected meteorological conditions and environmental conditions (potential environmental filters) in Breton Sound. To do this, correlation analysis was used between SSTA (lagged 0 to $12 \mathrm{mo}$ ) and monthly meteorological (atmospheric pressure, precipitation, air temperature, wind forcing) and environmental (water temperature, salinity, water level, Q) variables. This allowed determination of the length of ENSO events and their effect on meteorological and environmental conditions. Because ENSO typically affects weather in the southeast US during winter (McCabe \& Muller 2002), correlation analysis was also used to assess yearly seasonal relationships between SSTA and meteorological and environmental variable anomalies (winter and spring). One-way analysis of variance (ANOVA) was used to investigate differences in yearly winter and spring meteorological and environmental variable anomalies by ENSO category. Least squared means was used to investigate post hoc differences.

The next step linked juvenile brown shrimp abundance to SSTA and ENSO-related environmental filters. Correlation analysis was used to compare the monthly brown shrimp abundance with the SSTA (lag 0 to $12 \mathrm{mo}$ ), and stepwise regression analysis was used to explore relationships between monthly brown shrimp abundance and SSTA, meteorological, and environmental predictor variables. To examine the hypothesis that winter ENSO conditions affect spring abundance of juvenile brown shrimp, stepwise regression 
analysis was also performed on the yearly data to investigate seasonal effects. Stepwise regression (forward selection for entry and backward selection for elimination) was used to reduce the number of nonsignificant variables in the model. We chose $\alpha=0.10$ as the criterion for both entry and elimination; therefore, only variables significant at $\alpha=0.10$ were retained in the model (Kimmel et al. 2006). One-way ANOVA was used to investigate differences in spring juvenile brown shrimp abundance anomalies by winter ENSO classification. Least squared means was used to investigate post hoc differences.

The final step in establishing a teleconnection between ENSO and juvenile brown shrimp abundance in Breton Sound was to investigate ENSO-forced environmental filters and potential indirect environmental drivers (i.e. Mississippi River discharge, wind forcing, precipitation). To do this, stepwise regression analysis was used on the yearly winter and spring seasonal data to further explore relationships between significant ENSO-forced environmental filters and seasonal meteorological and environmental forcing. This would reveal any indirect meteorological and environmental forcing effects on brown shrimp abundance. Only variables significant at $\alpha=0.10$ were retained in the model.

\section{RESULTS}

\subsection{ENSO}

Analysis of the SSTA shows strong El Niño signals beginning in 1992 and occurring again in late 1997 and 2002 (Fig. 2). Strong La Niña signals were present beginning in early 1989, across 1999 and 2000, and in 2008. A total of 7 El Niño winters, 6 La Niña winters, and 7 neutral winters were identified from 1988-2007 (Table 1). Interestingly, of the 7 neutral winters, 6 of them showed positive SSTA, and only 1 showed a negative anomaly (1997). Correlation analysis between the SSTA index and monthly lagged SSTA suggested that, during the period of record, ENSO event durations were protracted, lasting up to 9 mo (Table 2).

\subsection{ENSO and weather}

Analysis of the monthly values showed that atmospheric pressure was the only monthly meteorological variable to show a direct significant (negative) relationship with lagged SSTA values (Table 2). Precipitation, which was highly correlated with atmospheric pressure $(p<0.0001)$, showed a positive, but nonsignificant relationship with lagged SSTA values.

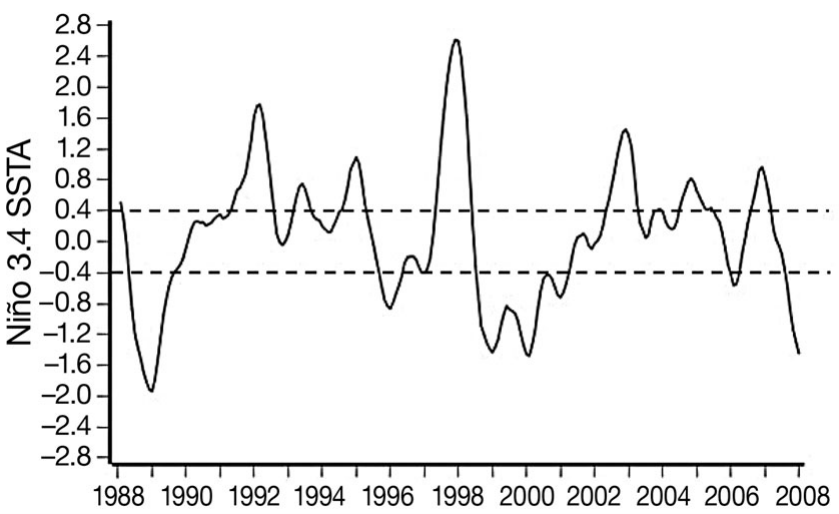

Fig. 2. Five month running mean of the Niño 3.4 sea surface temperature anomaly index (SSTA). Dashed lines border the neutral classification area. Values above (below) the upper dashed line correspond to El Niño (La Niña) months

Table 1. Classification of El Niño Southern Oscillation (ENSO) events in the winter season (January-March) for the period of record (1988-2007) and based on a 5 mo running mean of the Niño 3.4 sea surface temperature anomaly index (SSTA). Parentheses: running mean SSTA values

\begin{tabular}{|cccccc|}
\hline \multicolumn{2}{|c}{ El Niño } & \multicolumn{2}{c|}{ La Niña } & \multicolumn{2}{c|}{ Neutral } \\
Year & SSTA & Year & SSTA & Year & SSTA \\
\hline 1992 & $(1.72)$ & 1989 & $(-1.52)$ & 1988 & $(0.25)$ \\
1993 & $(0.41)$ & 1996 & $(-0.68)$ & 1990 & $(0.16)$ \\
1995 & $(0.76)$ & 1999 & $(-1.23)$ & 1991 & $(0.32)$ \\
1998 & $(1.98)$ & 2000 & $(-1.32)$ & 1994 & $(0.13)$ \\
2003 & $(0.86)$ & 2001 & $(-0.52)$ & 1997 & $(-0.18)$ \\
2005 & $(0.50)$ & 2006 & $(-0.50)$ & 2002 & $(0.01)$ \\
2007 & $(0.43)$ & & & 2004 & $(0.20)$ \\
\hline
\end{tabular}

When viewed by season, winter air pressure $(\mathrm{r}=-0.55$; $\mathrm{p}=0.01 ; \mathrm{N}=20)$ and temperature $(\mathrm{r}=-0.51 ; \mathrm{p}=0.02$; $\mathrm{N}=20$ ) correlated negatively with SSTA, and winter precipitation $(\mathrm{r}=0.53 ; \mathrm{p}=0.01 ; \mathrm{N}=20)$ correlated positively with SSTA. ANOVA results of winter weather patterns by ENSO categories showed negative pressure and temperature anomalies and positive precipitation anomalies during El Niño winters (Fig. 3). However, only temperature anomalies differed significantly by Niño category $\left(F_{2,17}=3.50 ; \mathrm{p}=0.05\right)$. Mean winter wind direction during the period of record was predominantly from the northeast. Winter wind forcing (velocity along the $110^{\circ}-290^{\circ}$ component) did not show a relationship to SSTA; however, analysis of winter wind forcing by ENSO category showed negative anomalies during El Niño winters and positive anomalies during La Niña winters (Fig. 3).

Spring weather patterns (air pressure, air temperature, precipitation) were not correlated with spring ENSO conditions. Spring wind direction during the period of record was mostly from the southeast. Spring wind forcing did not show a relationship to SSTA. 
Table 2. Pearson (r) correlations between Niño 3.4 sea surface temperature anomaly (SSTA) index (lagged 0-12 mo) and brown shrimp Farfantepenaeus aztecus abundance and environmental conditions in Breton Sound, Louisiana, USA. Data for SSTA, brown shrimp abundance, salinity, and water temperature are based on $\mathrm{N}=240$ monthly means. Data for water level are based on $\mathrm{N}=$ 192 monthly means. Data for Mississippi River discharge (Q) are based on monthly mean values calculated from daily discharge. NAVD: North American Vertical Datum, Q: daily Mississippi River discharge. Bold: significant at $\alpha=0.05$

\begin{tabular}{|c|c|c|c|c|c|c|c|c|c|c|}
\hline & \multirow[b]{2}{*}{$\begin{array}{c}\text { Niño } 3.4 \\
\text { SSTA }\end{array}$} & \multirow[b]{2}{*}{$\begin{array}{l}\text { Brown shrimp } \\
\text { abund. (n) }\end{array}$} & \multicolumn{4}{|c|}{ Weather variables } & \multirow[b]{2}{*}{$\begin{array}{c}\text { Salinity } \\
\text { (psu) }\end{array}$} & \multicolumn{2}{|c|}{ - Environmental variables } & \multirow[b]{2}{*}{$\begin{array}{c}\mathrm{Q} \\
\left(\mathrm{m}^{3} \mathrm{~s}^{-1}\right.\end{array}$} \\
\hline & & & $\begin{array}{l}\text { Air pressure } \\
(\mathrm{mb})\end{array}$ & $\begin{array}{l}\text { Precip } \\
\text { (cm) }\end{array}$ & $\begin{array}{c}\text { Air } \\
\text { temp. }\left({ }^{\circ} \mathrm{C}\right)\end{array}$ & $\begin{array}{l}\text { Wind forcing } \\
\left(\mathrm{m} \mathrm{s}^{-1}\right)\end{array}$ & & $\begin{array}{l}\text { Water } \\
\text { temp. }\left({ }^{\circ} \mathrm{C}\right)\end{array}$ & $\begin{array}{c}\text { Water level } \\
\text { (m NAVD 88) }\end{array}$ & \\
\hline \multicolumn{11}{|c|}{ Niño 3.4 SSTA } \\
\hline Lag 0 & - & -0.07 & -0.12 & 0.1 & -0.03 & -0.04 & -0.32 & -0.04 & 0.16 & 0.14 \\
\hline Lag 1 & 0.98 & -0.09 & -0.14 & 0.11 & -0.03 & -0.07 & -0.35 & -0.03 & 0.18 & 0.12 \\
\hline Lag 2 & 0.91 & -0.12 & -0.15 & 0.11 & -0.04 & -0.09 & -0.37 & -0.03 & 0.20 & 0.10 \\
\hline Lag 3 & 0.82 & -0.14 & -0.15 & 0.1 & -0.04 & -0.09 & -0.37 & -0.03 & 0.22 & 0.08 \\
\hline $\operatorname{Lag} 4$ & 0.70 & -0.16 & -0.15 & 0.11 & -0.04 & -0.06 & -0.37 & -0.04 & 0.24 & 0.07 \\
\hline Lag 5 & 0.58 & -0.19 & -0.14 & 0.12 & -0.03 & -0.04 & -0.36 & -0.04 & 0.26 & 0.07 \\
\hline Lag 6 & 0.45 & -0.21 & -0.14 & 0.11 & -0.02 & -0.01 & -0.37 & -0.03 & 0.28 & 0.06 \\
\hline $\operatorname{Lag} 7$ & 0.34 & -0.22 & -0.13 & 0.1 & -0.01 & 0.02 & -0.37 & -0.02 & 0.3 & 0.06 \\
\hline Lag 8 & 0.24 & -0.22 & -0.13 & 0.08 & 0.01 & 0.04 & -0.37 & -0.01 & 0.31 & 0.05 \\
\hline Lag 9 & 0.15 & -0.20 & -0.11 & 0.05 & 0.02 & 0.06 & -0.35 & 0.01 & 0.32 & 0.05 \\
\hline Lag 10 & 0.08 & -0.18 & -0.11 & 0.02 & 0.04 & 0.06 & -0.32 & 0.03 & 0.33 & 0.06 \\
\hline Lag 11 & 0.02 & -0.15 & -0.1 & 0.01 & 0.04 & 0.06 & -0.29 & 0.05 & 0.33 & 0.06 \\
\hline Lag 12 & -0.01 & -0.12 & -0.09 & 0.003 & 0.04 & 0.05 & -0.27 & 0.06 & 0.32 & 0.06 \\
\hline
\end{tabular}

\subsection{ENSO and environmental conditions}

Mean monthly salinity was lowest at Stn 244 and highest at Stn 251, and mean water temperature was similar at all stations (Table 3). Analysis of the monthly values showed that the SSTA index and all lagged SSTA values correlated significantly with salinity (negative) and water level (positive) in the basin (Table 2). There was no direct monthly relationship between SSTA and water temperature. River discharge correlated (positively) immediately with SSTA (Table 2). Winter discharge and precipitation anomalies were positively correlated $(\mathrm{r}=0.44 ; \mathrm{p}=0.05 ; \mathrm{N}=20$ ), and mean discharge anomalies were negative during $\mathrm{La}$ Niña winters (Fig. 3).

Analysis of the yearly winter-spring relationships showed that winter SSTA correlated significantly (negatively) with spring salinity ( $\mathrm{r}=-0.54 ; \mathrm{p}=0.01 ; \mathrm{N}=20$ ), but did not correlate with spring water temperature. ANOVA testing of spring salinity and water temperature anomalies by ENSO categories indicated a significant salinity difference $\left(F_{2,17}=3.50 ; \mathrm{p}=0.05\right)$ driven by the pattern of negative spring salinity anomalies following El Niño winters and positive salinity anomalies following La Niña winters ( $t=3.39 ; \mathrm{p}=0.003 ;$ Fig. 4). Spring water temperature anomalies were near 0 following El Niño winters and positive following La Niña winters.

\subsection{ENSO and juvenile brown shrimp abundance}

Mean juvenile brown shrimp abundance in the seine samples was highest during the spring (April-June;
Fig. 5). Based on correlation analyses, we identified a significant ENSO signal in brown shrimp abundance at a 3 mo lag, and the negative relationships between SSTA and brown shrimp abundance were protracted for several months (Table 2). Stepwise regression showed that monthly brown shrimp abundance could be predicted by the 3 mo lagged SSTA (brown shrimp $\left.=-0.10[\log 3]+0.01 ; \mathrm{r}^{2}=0.02 ; \mathrm{p}<0.03 ; \mathrm{N}=237\right)$. While the analysis was originally performed with all lags, the Lag 3 term was the only one included in the model. This choice was made because: (1) it was the first lag term to have a significant correlation; (2) it was biologically significant; and (3) it had the highest negative correlation with salinity. Multiple lag terms could not be included due to multicollinearity issues.

When analyzed by year, the winter (January to March) SSTA index did not correlate with spring brown shrimp abundance anomalies for the combined variable or for each station individually. Stepwise regression of the yearly seasonal averages showed that the spring brown shrimp abundance anomaly could only be predicted by spring salinity and spring air temperature (brown shrimp anomaly $=0.37$ [salinity] - 0.39 [air temperature] - 1.77; $\mathrm{p}=0.005 ; \mathrm{r}^{2}=0.56$; $\mathrm{N}=20$ ). Examination of the coefficient of partial determination showed that salinity $\left(\mathrm{r}^{2}=0.36\right)$ dominated the relationship. ANOVA of brown shrimp anomalies by ENSO categories showed a pattern of negative spring brown shrimp anomalies following El Niño winters and positive spring brown shrimp anomalies following La Niña winters (Fig. 4). However, this relationship was not statistically significant $\left(F_{2,17}=\right.$ $0.50, \mathrm{p}=0.62)$. 

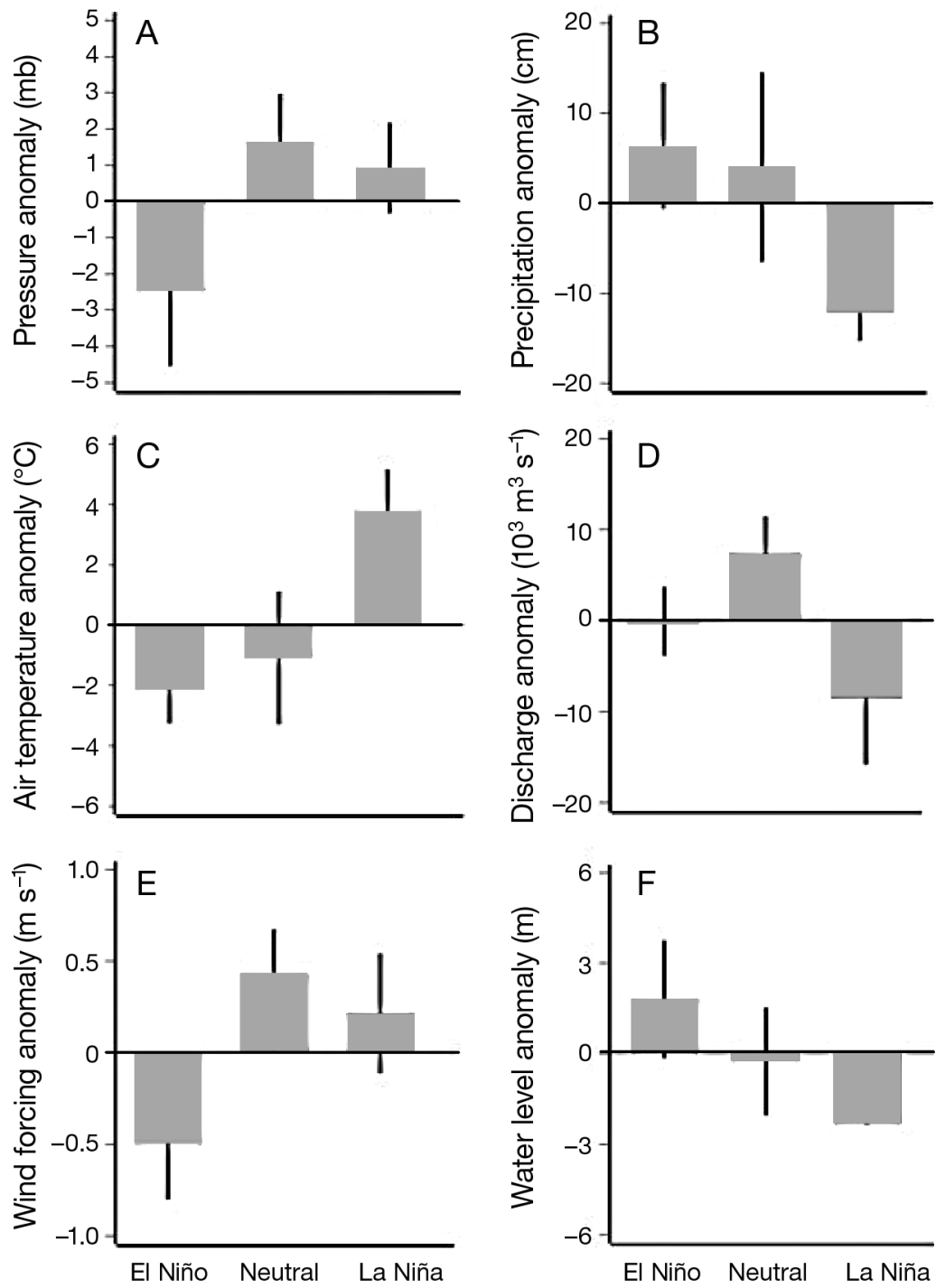

Fig. 3. Mean (SE) winter (January-March), (A) surface atmospheric pressure, (B) precipitation, (C) air temperature, (D) Mississippi River discharge, (E) wind forcing, and (F) water level anomalies by El Niño Southern Oscillation (ENSO) classification. Air pressure, precipitation, air temperature, and wind forcing variables were measured at New Orleans International Airport (Stn ID 166295). Mississippi River discharge was measured at Tarbert's Landing, Mississippi (Gage ID USACE 01100). Water level was measured at USGS 07374527 Northeast Bay Gardene near Point-a-la-Hache, Louisiana. Anomalies for A-E are based on the period of record, 1988-2007, and anomalies for F are based on the period of record 1992-2007

\subsection{ENSO-forced environmental filters}

Stepwise regression analysis of the yearly spring salinity against all winter and spring meteorological and environmental variables showed that spring salinity was predicted by winter discharge, spring precipitation, and winter wind forcing (salinity $=-0.0002[\mathrm{Q}]-$ 0.10 [precip] +2.13 [wind forcing] $+9.29 ; \mathrm{p}=0.004 ; \mathrm{r}^{2}=$ $0.66 ; \mathrm{N}=20$ ). Examination of the coefficient of partial determination showed that winter discharge $\left(r^{2}=0.37\right)$ dominated the relationship, followed by spring precipitation $\left(\mathrm{r}^{2}=0.18\right)$ and winter wind forcing $\left(\mathrm{r}^{2}=0.10\right)$.

\section{DISCUSSION}

The results identified a teleconnection between juvenile brown shrimp abundance in Breton Sound estuary and ENSO. ENSO affected winter weather conditions (air pressure, temperature, and precipitation) and spring brown shrimp abundance in Breton Sound. Juvenile brown shrimp abundance effects lagged ENSO by 3 mo; lower than average abundances of juvenile brown shrimp were caught in springs following winter El Niño events, and higher than average abundances of brown shrimp were caught in springs following La Niña winters. Salinity was the dominant ENSOforced environmental filter for juvenile brown shrimp. Spring salinity was cumulatively forced by winter river discharge, winter wind forcing, and spring precipitation.

\subsection{ENSO and weather}

ENSO effects on winter weather patterns in Breton Sound agreed with those found by other researchers in Louisiana (McCabe \& Muller 2002) and the southeastern United States (Ropelewski \& Halpert 1986, Schmidt et al. 2001). El Niño winters were marked by lower than normal pressure and temperature and higher than normal precipitation, most likely driven by enhanced formation of winter storms in the GOM (Hsu 1993, Hardy \& Hsu 1997, Vega et al. 1998). Conversely, La Niña winters were marked by positive winter temperature and pressure anomalies and negative precipitation anomalies. These meteorological effects are driven by change in the strength of the subtropical jet stream. The subtropical jet stream increases in strength during El Niño events and decreases in strength during La Niña events. A strengthened subtropical jet stream increases the likelihood of precipitation in the southeastern United States due to a combination of an increase in atmospheric moisture entrainment from the 
Table 3. Monthly mean \pm SE (range) values of spring (AprilJune) salinity and water temperature variables as measured at 4 fisheries independent seine net collection stations (244, $255,250,251$ ) in Breton Sound estuary, Louisiana, during the period of record (1988-2007)

\begin{tabular}{|ccc|}
\hline Stn & Salinity (psu) & Water temperature $\left({ }^{\circ} \mathrm{C}\right)$ \\
\hline 244 & $3.2 \pm 0.3(0.4-8.9)$ & $26.1 \pm 0.5(17.8-33.7)$ \\
255 & $3.7 \pm 0.3(0.6-9.1)$ & $26.2 \pm 0.5(16.9-32.4)$ \\
250 & $4.9 \pm 0.4(1.0-11.6)$ & $26.1 \pm 0.5(15.8-32.0$ \\
251 & $9.1 \pm 0.5(2.0-19.6)$ & $25.5 \pm 0.6(9.4-33.2)$ \\
\hline
\end{tabular}
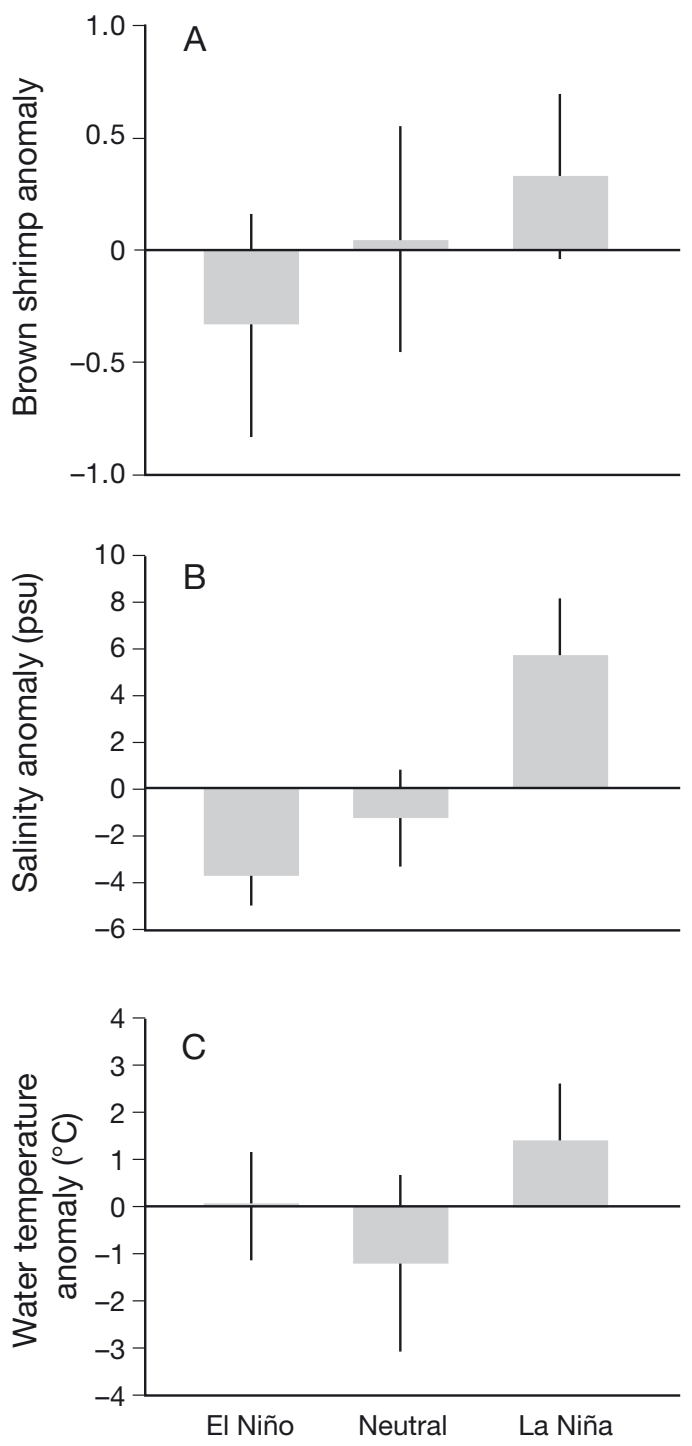

Fig. 4. Mean (SE) spring (April-June), (A) brown shrimp, (B) salinity, and (C) water temperature anomalies by El Niño Southern Oscillation (ENSO) classification, based on the period of record (1988-2007). Brown shrimp abundance, salinity, and water temperature variables were measured at 4 fisheries independent seine net collection stations $(244,255,250$, 251) in Breton Sound estuary, Louisiana. Mean brown shrimp anomalies are based on normalized abundance data

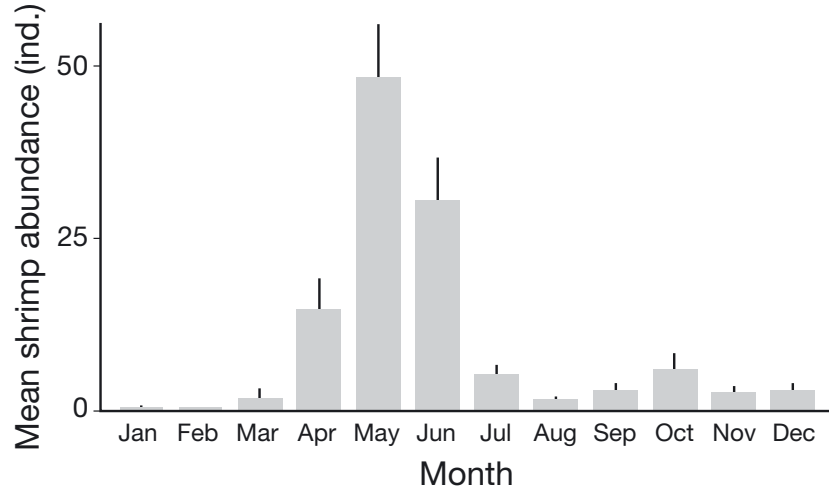

Fig. 5. Mean (SE) monthly shrimp catch in seine samples in Breton Sound estuary, Louisiana, USA from 1988-2007. Means are based on a combined mean from 4 fisheries independent seine net collection stations $(244,255,250,251)$

tropics and the southward displacement of frontal systems (Ropelewski \& Halpert 1986, Schmidt et al. 2001, McCabe \& Muller 2002). Conversely, when the subtropical jet weakens, frontal systems are displaced farther northward, resulting in a decreased likelihood of precipitation.

\subsection{ENSO and brown shrimp}

The teleconnection between brown shrimp abundance and ENSO first became apparent after $3 \mathrm{mo}$, and its effects were detectable for up to 9 mo. This result is consistent with research showing that ENSO events typically begin in early winter and peak in strength between 3 and 9 mo later (Horel \& Wallace 1981). The 3 mo lagged SSTA was able to predict monthly juvenile brown shrimp abundance, but mean winter SSTA did not directly predict spring brown shrimp abundance. This lack of predictability in the seasonal data may be an artifact of increased variability in the aggregated data, particularly for juvenile brown shrimp abundance. Although seine data are highly variable (Rozas \& Minello 1997), the sampling technique likely did not drive the high variability.

While the monthly relationship between brown shrimp and ENSO became significantly related after $3 \mathrm{mo}$, we observed low correlation ( 2 to $4 \%$ ) between the variables. This phenomenon is not uncommon in studies that link ecological processes with climate patterns (e.g. see Bradbury et al. 2002 for Pacific/North American teleconnection, North Atlantic Oscillation and streamflow; Meynecke et al. 2006 for Southern Oscillation Index and commercial fish catch) and was likely the result of the large amount of combined variability (noise) inherent in the combination of physical (climate) and ecological data (Stenseth et al. 2002). Statistical modeling simulations performed on prairie plant communities have shown 
that weak climate-community effects are the result of community stochasticity caused by species-specific responses to the environment, life history characteristics, and temporal variability of species performance, which itself reflects the environmental variability (Adler et al. 2009). In our study, the large variability observed in the abundance data was likely the result of a combination of high stochastic variability associated with the environmental variables and the spatiotemporal patchiness in distribution of brown shrimp (i.e. seasonal migration, sampling variability) in the estuary over the $20 \mathrm{yr}$ time series, which is considered short for climate studies. Ecological data are inherently variable, because data are highly field-based, adding an additional level of bias (Jager \& Looman 1995, Hilborn \& Mangel 1997). Therefore, the correlations represented highly complex relationships between explanatory variables with inherent process uncertainty coupled with a response variable that contains both process (i.e. life history stage, migration) and observation uncertainty (Hilborn \& Mangel 1997). However, even with the high variability in the fisheries data, we were able to identify a teleconnection between ENSO and local brown shrimp abundance that lasted throughout the protracted ENSO events. These patterns are likely physically meaningful and, as longer time series become available, the relationships may become stronger.

\subsection{ENSO-forced environmental filters}

Estuarine salinity was the dominant ENSO-related environmental filter that affected juvenile brown shrimp abundance in Breton Sound. This finding differs from an earlier study in Barataria estuary, Louisiana (Childers et al. 1990). In that study, brown shrimp harvests (1963-1988) were curvilinear, showing lower than normal harvest during both El Niño and La Niña events and greatest harvest during neutral years. We attribute this discrepancy to the difference in environmental filters between the 2 studies. Childers et al. (1990) concluded that water level was the dominant environmental filter, with low water levels during La Niña events precluding the marsh surface from postlarval settlement. During El Niño events, while water levels were high, salinity was lowered, forced primarily by increased local precipitation. Neutral years provided both adequate water levels and salinity conditions which enhanced settlement and growth. In our study, water level was also related to ENSO conditions; however, it did not appear to directly affect juvenile brown shrimp. We attribute this to the fact that, unlike their study, where the estuary was highly separated from riverine forcing with continuous levees on 3 sides, Breton Sound is more connected to the Mississippi
River. As such, spring water levels in Breton Sound are typically high; the difference is the component that dominates water levels - fresh or saline water.

Salinity was cumulatively forced by winter river discharge and wind forcing and spring precipitation. Fluvial and atmospheric forcing have been shown to exert strong control over estuarine conditions in Breton Sound (Snedden et al. 2007b). Breton Sound is connected to the Mississippi River in the upper basin via Caernarvon and in the lower basin via overbank flooding. We compared pre- and post-Caernarvon data to determine whether the diversion affected brown shrimp abundance values. While this testing showed no significant Caernarvon effect in the analysis, the combination of restored riverine connectivity and natural flooding can significantly act to freshen the estuary. The results also showed a pattern of more onshore wind flow during La Niña winters and greater offshore wind flow during El Niño winters. This is consistent with the ENSO-related variability in the frequency and intensity of 2 of the 8 synoptic weather types described by Muller (1977), viz. frontal overrunning and Gulf Return, that are influenced by ENSO in this region, primarily in the winter (McCabe \& Muller 2002). In addition, there is strong linkage between remote atmospheric forcing and coastal water levels in Breton Sound (Snedden et al. 2007b). The linkage of these environmental drivers to salinity suggests both local and regional ENSO control over brown shrimp abundance.

Winter river discharge was related to local winter precipitation (at New Orleans, Louisiana), but the fact that discharge was measured at Tarbert Landing, Mississippi, over 402 river $\mathrm{km}$ north of Breton Sound, suggests that that ENSO-forced regional weather patterns, far removed from the estuary, were affecting salinity (by way of dilution from Mississippi River discharge) and local brown shrimp abundance. Local precipitation has been shown to strongly affect river discharge for small rivers in the southeastern US (Schmidt et al. 2001). Mississippi River discharge, however, is often difficult to link to ENSO forcing conditions because the Mississippi River integrates the response of the water budget across a large region (Twine et al. 2005). Therefore, the effects of ENSO forcing upstream (which may be opposite to that measured in the estuary) are translated to downstream locations, causing different discharge from what is expected (Twine et al. 2005).

Remote alongshore wind forcing is a large-scale process that is vital to estuary-shelf exchange and estuarine circulation in northern GOM estuaries, and specifically Louisiana estuaries, through Ekman processes (Snedden et al. 2007b). Unlike East Coast estuaries, where atmospheric components dominate water levels, microtidal estuaries in the GOM are heavily reliant on synoptic meteorological forcing to drive coastal 
water levels and promote estuary-shelf exchange (Rozas 1995). Therefore, wind-driven tides are critical in this region for regulation of estuarine salinity. Additionally, tides are critical for post-larval stocking of many estuarine dependent species (Epifanio 1995, Brown et al. 2000, Möller et al. 2009), and brown shrimp are highly dependent on tides to transport them to vegetated marshes where they settle (Zimmerman et al. 2000, Haas et al. 2001, Roth et al. 2008). While the increase in onshore currents earlier in the season may have affected stocking rates, the data were not able to show this connection. To directly assess the effect of this ENSO-forced environmental driver on brown shrimp stocking, it would be necessary to investigate data on postlarval shrimp abundance (i.e. Haas et al. 2001). The results, however, did show that ENSOforced winter synoptic wind patterns affected salinity and, consequently, juvenile brown shrimp abundance.

ENSO-forced variability in estuarine salinity has been shown to regulate abundance of penaeid prawns in the Gulf of California (Galindo-Bect et al. 2000) and Australian and Brazilian estuaries (Meynecke et al. 2006, Möller et al. 2009). Salinity also affects the abundance of juvenile brown shrimp in Breton Sound (Rozas et al. 2005) and other Louisiana estuaries (Haas et al. 2001, Roth et al. 2008). However, some penaeid prawns, including brown shrimp, show high physiological resilience to lowered salinity during the juvenile life stage (Larson et al. 1989, Zimmerman et al. 1990, GalindoBect et al. 2000). Therefore, the consistent positive relationship between salinity and brown shrimp abundance may not reflect a direct physiological intolerance to lowered salinity but rather an unmeasured indirect trophic effect of lowered prey items in fresher conditions or, conversely, preference for prey items in higher salinity areas (Zimmerman et al. 1990). While this was not a focus of our study, 2 recent studies in Louisiana estuaries suggest that production of juvenile brown shrimp is retarded in depressed salinities, owing largely to reduced growth rates (L. Rozas and T. Minello unpubl. data, Adamack unpubl. data).

Indirect trophic effects of climate regulation on species abundance through control of the spatial and temporal distribution of prey species have been documented in many habitats (match-mismatch hypothesis; Stenseth et al. 2002). For example, biochemical analysis of lipid tissue has documented opposite population-level responses in pelagic versus demersal fish species in boreal ocean (Gulf of Alaska, Bearing Sea, Scotian Shelf, and North Sea) fish communities and related these to climate-mediated change in essential fatty acid production by phytoplankton (Litzow et al. 2006). Likewise, changes in the abundance of a dominant zooplankton species (Calanus finmarchicus) were related to large-scale freshening in the
Gulf of Maine, as well as to changes in fish community structure (Pershing et al. 2005). While no such indirect prey effects have been uncovered for the northern GOM, 3 studies in northern GOM estuaries have documented a salinity-moderated teleconnection between ENSO and the common oyster pathogen Perkinsus marinus that has large-scale indirect effect on oyster populations through regulation of growth and fitness (Kim \& Powell 1998, Soniat et al. 2005, 2009).

\subsection{Neutral ENSO years}

With the exception of atmospheric pressure and wind forcing, winter weather patterns and river discharge during neutral years resembled El Niño years. Similarly, spring salinity and water temperature during neutral years resembled El Niño events. This likely resulted from the fact that 6 of the 7 neutral years had positive SSTA values, 2 of which $(1988,1991)$ were close to the cutoff value for classification as an El Niño event. It is interesting that during neutral years, surface atmospheric pressure and wind forcing, a function of atmospheric pressure (McCabe \& Muller 2002), responded in a manner consistent with La Niña events. This is likely because of cyclogenesis, or the lack thereof, during various phases of ENSO. During neutral and La Niña winters, GOM cyclogenesis is less frequent, winds are primarily onshore from the southeast, and regional atmospheric pressure tends to be higher. Conversely, GOM cyclogenesis during winter El Niño events serves to lower regional atmospheric pressure. Since these GOM storms mostly form in the western GOM off the coast of Texas and then track east to northeastward along the GOM coast (Whittaker \& Horn 1984), this brings the core of the storm toward the study area, reinforcing the lower pressure locally, as measured at New Orleans.

\subsection{Management implications}

Although we did not further investigate the specific mechanisms through which climate affects shrimp populations, the results illuminate an important factor to consider when managing the fishery or restoring coastal wetland habitat. Large winter/spring freshwater releases through the Caernarvon Freshwater Diversion are conducted annually in Breton Sound estuary. These releases are designed to restore the natural flooding conditions that would exist absent the extensive levee system that separates the estuary from the Mississippi River. Often, these freshwater releases are perceived to be at odds with the brown shrimp fishery because of the possible effects on juvenile survival 
and growth in the estuary. While juvenile recruitment and survival are important to the year-class strength of the fishery resource (Haas et al. 2001, Calliouet et al. 2008), the data indicate that all years are not created equal. This information can assist managers to develop forward-looking strategies that balance the need for fresh water with the needs of the fishery by maximizing potential benefits to each when conditions are conducive. For example, it may not be advantageous to manage for 'average' conditions every year, but rather, a boom-and-bust method should be considered, whereby large freshwater releases are maximized during El Niño events when shrimp abundance is low and vice versa. We suggest that resource managers begin incorporating knowledge of climate-induced effects on estuarine resources, especially in the context of future changes in sea level, river discharge, fishing pressure, and other climatically and anthropogenically-induced environmental conditions.

Acknowledgements. We thank M. Beck (Louisiana Department of Natural Resources) for support with data sets. G. Snedden (US Geological Survey, USGS) provided help with and discussion of data analysis. M. Fischer (USGS) provided assistance with the study area map and review of the manuscript. G. McCabe (USGS), L. Rozas (National Oceanic and Atmospheric Administration), K. Rose (Louisiana State University, LSU), and J. Cable (LSU) provided reviews of the manuscript. This work was funded by the Louisiana Department of Wildlife and Fisheries through support of the USGS Louisiana Cooperative Fish and Wildlife Research Unit.

\section{LITERATURE CITED}

Adler PB, Hille Ris Lambers J, Levine M (2009) Weak effects of climate variability on coexistence in a sagebrush steppe community. Ecology 90:3303-3312

Blenckner T, Hillebrand H (2002) North Atlantic Oscillation signatures in aquatic and terrestrial ecosystems - a metaanalysis. Glob Change Biol 8:203-212

Bradbury JA, Dingman SL, Keim BD (2002) New England drought and relations with large scale atmospheric circulation patterns. J Am Water Res Assoc 38:1287-1299

Brown CA, Jackson GA, Brooks DA (2000) Particle transport through a narrow tidal inlet due to tidal forcing and implications for larval transport. J Geophys Res 105: 24141-24156

Burd AB, Jackson GA (2002) An analysis of water column distributions in Florida Bay. Estuaries 25:570-585

> Calliouet CW Jr, Hart RA, Nance JM (2008) Growth overfishing in the brown shrimp fishery of Texas, Louisiana, and adjoining Gulf of Mexico EEZ. Fish Res 92:289-302

Childers DL, Day JW Jr, Muller RA (1990) Relating climatological forcing to coastal water levels in Louisiana estuaries and the potential importance of El Niño-Southern Oscillation events. Clim Res 1:31-42

Christensen JH, Hewitson B, Susuioc A, Chen A and others (2007) Regional climate projections. In: Solomon S, Qin D, Manning M, Chen Z, Marquis M, Averyt KB, Tignor M, Miller HL (eds) Climate change 2007: the physical science basis. Contribution of Working Group I to the 4th assessment report of the Intergovernmental Panel on Climate Change. Cambridge University Press, Cambridge

Emery WJ, Thompson RE (1998) Data analysis methods in physical oceanography, 1st edn. Elsevier Science, Amsterdam

Epifanio CE (1995) Transport of blue crab (Callinectes sapidus) larvae in the waters off mid-Atlantic states. Bull Mar Sci 57:713-725

Galindo-Bect MS, Glenn EP, Page HM, Fitzsimmons K and others (2000) Penaeid shrimp landings in the upper Gulf of California in relation to Colorado River discharge. Fish Bull 98:222-225

> Garcia AM, Vieira JP, Winemiller KO, Grimm AM (2004) Comparison of 1982-1983 and 1997-1998 El Niño effects on the shallow water fish assemblage of the Patos Lagoon Estuary (Brazil). Estuaries 27:905-914

Glantz MH (1996) Currents of change: El Niño's impact on climate and society. Cambridge University Press, Cambridge

> Graham NE, White WB (1988) The El Niño cycle: a natural oscillator of the Pacific Ocean - atmosphere system. Science 240:1293-1301

> Haas HL, Lamon EC III, Rose KA, Shaw RF (2001) Environmental and biological factors associated with the stagespecific abundance of brown shrimp (Penaeus aztecus) in Louisiana: applying a new combination of statistical techniques to long-term monitoring data. Can J Fish Aquat Sci 58:2258-2270

> Haas HL, Rose KA, Fry B, Minello TJ, Rozas LP (2004) Brown shrimp on the edge: linking habitat to survival using an individual-based simulation model. Ecol Appl 14: 1232-1247

Hardy JW, Hsu SA (1997) Climatology of winter cyclogenesis intensity in the northwest Gulf of Mexico. Natl Weather Dig 22:3-7

Hilborn R, Mangel M (1997) The ecological detective: confronting models with data. Princeton University Press, Princeton, NJ

> Horel JD, Wallace JM (1981) Planetary-scale atmospheric phenomena associated with the southern oscillation. Mon Weather Rev 109:813-829

Hsu SA (1993) The Gulf of Mexico - a breeding ground of winter storms. Mar Weather Log 10-11:4-7

Jager JC, Looman CWN (1995) Data collection. In: Jongman RHG, Ter Braak CJF, Van Tongeren OFR (eds) Data analysis in community and landscape ecology. Cambridge University Press. Cambridge, p 10-27

Kennedy AJ, Griffin ML, Morey SL, Smith SR, O'Brien JJ (2007) Effects of El Niño-Southern Oscillation on sea level anomalies along the Gulf of Mexico coast. J Geophys Res 112:C05047. doi:10.1029/2006JC003904

Kim Y, Powell EN (1998) Influence of climate change on interannual variation in population attributes of Gulf of Mexico oysters. J Shellfish Res 17:265-274

Kimmel DG, Miller WD, Roman MR (2006) Regional scale climate forcing of mesozooplankton dynamics in Chesapeake Bay. Estuar Coast 29:375-387

Larson SC, Van Den Avyle MJ, Bozeman EL Jr (1989) Species profiles: life histories and environmental requirements of coastal fishes and invertebrates (South Atlantic) - brown shrimp. US Fish Wildl Serv Biol Rep 82(11.90)

Lehodey P, Bertignac M, Hampton J, Lewis A, Picaut J (1997) El Niño Southern Oscillation and tuna in the western Pacific. Nature 389:715-718

Lipp EK, Schmidt N, Luther ME, Rose JB (2001) Determining the effects of El Niño-Southern Oscillation events on coastal water quality. Estuaries 24:491-497 
Litzow MA, Bailey KM, Prahl FG, Heintz R (2006) Climate regime shifts and reorganization of fish communities: the essential fatty acid limitation hypothesis. Mar Ecol Prog Ser 315:1-11

Louisiana Department of Wildlife and Fisheries (LDWF) (2002) Marine fisheries division: field procedures manual, version 02-1. LDWF, Office of Fisheries, Marine Fisheries Division. Baton Rouge, LA

Mantua NJ, Hare SR, Zhang Y, Wallace JM, Francis RC (1997) A Pacific interdecadal climate oscillation with impacts on salmon production. Bull Am Meteorol Soc 78:1069-1079

McCabe GJ, Muller RA (2002) Effects of ENSO on weathertype frequencies and properties at New Orleans, Louisiana, USA. Clim Res 20:95-105

Ménard F, Marsac F, Bellier E, Cazelles B (2007) Climatic oscillations and tuna catch rates in the Indian Ocean: a wavelet approach to time series analysis. Fish Oceanogr 16:95-104

Meynecke JO, Lee SY, Duke NC, Warnken J (2006) Effect of rainfall as a component of climate change on estuarine fish production in Queensland, Australia. Estuar Coast Shelf Sci 69:491-504

Möller OO Jr, Castello JP, Vaz AC (2009) The effect of river discharge and winds on the interannual variability of the pink shrimp Farfantepenaeus paulensis production in Patos lagoon. Estuar Coast 32:787-796

Muller RA (1977) A synoptic climatology for environmental baseline analysis: New Orleans. J Appl Meteorol 16:20-33

Noel J, Changnon D (1998) A pilot study examining U.S. winter cyclone frequency patterns associated with three ENSO parameters. J Clim 11:2152-2159

> Palmer MA, Reidy Liermann CA, Nilsson C, Flörke M, Alcamo J, Lake PS, Bond N (2008) Climate change and the world's river basins: anticipating management options. Front Ecol Environ 6:81-89

Pershing AJ, Greene CH, Jossi JW, O'Brien L, Brodziak JKT, Bailey BA (2005) Interdecadal variability in the Gulf of Maine zooplankton community, with potential impacts on fish recruitment. ICES J Mar Sci 62:1511-1523

Piazza BP, La Peyre MK (2007) Restoration of the annual flood pulse in Breton Sound, Louisiana, USA: habitat change and nekton community response. Aquat Biol 1: 109-119

Riascos JM (2006) Effects of El Niño-Southern Oscillation on the population dynamics of the tropical bivalve Donax dentifer from Málaga Bay, Columbian Pacific. Mar Biol 148:1283-1293

Ropelewski CF, Halpert MS (1986) North American precipitation and temperature patterns associated with El Niño/ Southern Oscillation (ENSO). Mon Weather Rev 114: 2352-2362

Ropelewski CF, Halpert MS (1987) Global and regional scale precipitation patterns associated with the El Niño/Southern Oscillation. Mon Weather Rev 115:1606-1626

Roth BM, Rose KA, Rozas LP, Minello TJ (2008) Relative influence of habitat fragmentation and inundation on brown shrimp Farfantepenaeus aztecus production in northern Gulf of Mexico salt marshes. Mar Ecol Prog Ser 359: 185-202

Rozas LP (1995) Hydroperiod and its influence on nekton use of the salt marsh: a pulsing ecosystem. Estuaries 18: 579-590

Rozas LP, Minello TJ (1997) Estimating densities of small

Editorial responsibility: Mauricio Lima,

Santiago, Chile fishes and decapod crustaceans in shallow estuarine habitats: a review of sampling design with focus on gear selection. Estuaries 20:199-213

> Rozas LP, Minello TJ, Munuera-Fernandez I, Fry B, Wissel B (2005) Macrofaunal distributions and habitat change following winter-spring pulsed releases of freshwater into the Breton Sound estuary, Louisiana. Estuar Coast Shelf Sci 65:319-336

Schmidt N, Luther ME (2002) ENSO impacts on salinity in Tampa Bay, Florida. Estuaries 25:976-984

> Schmidt N, Lipp EK, Rose JB, Luther ME (2001) ENSO influences on seasonal rainfall and river discharge in Florida. J Clim 14:615-628

> Snedden GA, Cable JE, Swarzenski C, Swenson E (2007a) Sediment discharge into a subsiding Louisiana deltaic estuary through a Mississippi River diversion. Estuar Coast Shelf Sci 71:181-193

Snedden GA, Cable JE, Wiseman WJ (2007b) Subtidal sea level variability in a Mississippi River deltaic estuary, Louisiana. Estuaries Coasts 30:802-812

Soniat TM, Klinck JM, Powell EN, Hofmann EE (2005) Understanding the success and failure of oyster populations: climatic cycles and Perkinsus marinus. J Shellfish Res 25: 83-93

Soniat TM, Hofmann EE, Klinck JM, Powell EN (2009) Differential modulation of eastern oyster (Crassostrea virginica) disease parsites by El Niño - Southern Oscillation and the North Atlantic Oscillation. Int J Earth Sci 98:99-114

> Stenseth NC, Mysterud A, Otterson G, Hurrell JW, Chan KS, Lima M (2002) Ecological effects of climate fluctuations. Science 297:1292-1296

Tolan JM (2007) El Niño-Southern Oscillation impacts translated to the watershed scale: estuarine salinity patterns along the Texas coast. Estuar Coast Shelf Sci 72:247-260

Tonn WM (1990) Climate change and fish communities: a conceptual framework. Trans Am Fish Soc 119:337-352

Trenberth KE (1997) The definition of El Niño. Bull Am Meteorol Soc 78:2771-2777

- Trenberth KE, Caron JM (2000) The southern oscillation revisited: sea level pressures, surface temperatures, and precipitation. J Clim 13:4358-4365

Twine TE, Kucharik CJ, Foley JA (2005) Effects of El Niño Southern Oscillation on the climate, water balance, and streamflow of the Mississippi River basin. J Clim 18: 4840-4860

Vega AJ, Rohli RV, Henderson KG (1998) The Gulf of Mexico mid-tropospheric response to El Niño and La Niña forcing. Clim Res 10:115-125

Weiher E, Keddy P (1999) Ecological assembly rules: perspectives, advances, retreats. Cambridge University Press, Cambridge

Whittaker LM, Horn LH (1984) Northern hemisphere extratropical cyclone activity for four mid-season months. J Climatol 4:297-310

Zimmerman RJ, Minello TJ, Smith DL, Kostera J (1990) The use of Juncus and Spartina marshes by fisheries species in Lavaca Bay, Texas, with reference to the effects of floods. NOAA Tech Memo NMFS-SEFC-251

Zimmerman RJ, Minello TJ, Rozas LP (2000) Salt marsh linkages to productivity of penaeid shrimps and blue crabs in the northern Gulf of Mexico. In: Weinstein MP, Kreeger DA (eds) Concepts and controversies in tidal marsh ecology. Kluwer, Dordrecht, p 293-314

Submitted: June 29, 2009; Accepted: June 28, 2010

Proofs received from author(s): July 23, 2010 